International Journal of Engineering \& Technology, 7 (4.38) (2018) 676-681
International Journal of Engineering \& Technology
SPC
Website $:$ www.sciencepubco.com/index.php/IJET
Research paper

\title{
The Study of Value-Semantic Orientation Problem in the Context of Professional and Personal Self-Development of Future Teachers
}

\author{
Madina Zhilgildinova ${ }^{1 *}$, Adlet Dyusembaevich Kariyev ${ }^{2}$, Aiman Toktacinovna Selkebayeva ${ }^{3}$, Guliya Alikhankyzy $^{4}$ \\ Beibitgul Turganbayeva ${ }^{5}$ \\ ${ }^{1}$ L.N. Gumilyov Eurasian National University (ENU), Satpayev Str., 2, Astana, 010008, Republic of Kazakhstan \\ ${ }^{2}$ Sholem Aleichem Amur State University, Shirokaya Str., 70, Jewish Autonomous Region, Birobidzhan, 679015, Russia \\ ${ }^{3}$ Almaty University, Almaty, Kazakhstan, B.Momyshuly, St., 36, Aksai 3-th micro-district, Almaty, 050007, Republic of Kazakhstan \\ ${ }^{4}$ Abai Kazakh National Pedagogical University, Dostyk avenue, 13, Almaty, 050010, Republic of Kazakhstan \\ ${ }^{5}$ Shakarim State University of Semey, Glinka St., 20a, Semey, 070000, Republic of Kazakhstan \\ *Corresponding author E-mail: zhilgildinova.m@mail.ru
}

\begin{abstract}
The article presents the empirical research results aimed at determining the level of mastering the abilities to professional and personal self-development of pedagogical specialty students. Based on the analysis of psychological and pedagogical literature, the concept of "self-development of future teachers" was defined and formulated. The study offers a detailed prognostic model of stimulation of professional and personal self-development of future teachers. Based on system analysis, the authors have defined and presented the structure of stimulation of professional and personal self-development of future teachers. In the proposed structure of stimulation, the authors distinguished motivational, cognitive, and value-semantic components.

The study comprehensively examines the value-semantic component as one of the main factors stimulating the professional and personal self-development of pedagogical specialty students. The results of empirical research on stimulation of professional and personal selfdevelopment of future teachers are presented using diagnostic methodologies.
\end{abstract}

Keywords: Components of professional and personal self-development; Professional and personal competences; Professional development; Stimulation; Value-semantic orientations.

\section{Introduction}

The increased requirements for the professional training of newbreed teachers require a review of the future teacher training at the university, creating the basis for the formation of his professional and personal self-development. Graduates of pedagogical specialties, entering into professional activity, face problems, the analysis of which has led to the conclusion that many teachers in practice do not know what to focus on, what aspects of their knowledge should be taken into account in the specifics of their professional development.

Thus, at present, one of the strategic directions in professional training of pedagogical specialty students is the development of abilities and qualities of the future specialists, who along with knowledge bear competence and are guaranteed to be ready for performing their professional functions. But in the educational process, as a rule, students do not have the opportunity to show in practice the degree of their readiness for the profession, since they are in the position of the educational services consumers, who assimilate fundamental knowledge, without thinking deeply about their professional purpose and personal becoming.

A significant contribution to the study of issues concerning theory and methodology of professional education was made by Kazakhstan scientists S.A. Abdraman, S.A. Abdymanapov, G.K. Akhmetova, K.M. Aryngazin, S.T. Kargin, K.Zh. Kozhakhmetova,
S.Z. Kokanbaev, A.S. Magauova, N.A. Minzhanov, A.P. Seiteshev, B.G. Sarsenbaeva, Sh.T. Taubaeva, N.D. Khmel, et al. Various aspects of professional training of future teachers is presented in researches of Kazakhstan scientists B.A. Abdykarimov, K.Zh. Aganina, G.M. Kertaeva, G.Zh. Menlibekova, T.K. Boleev, E.I. Burdina, A.A. Kalyuzhny, et al.

The conceptual foundations of the personal and professional selfdevelopment theory are reflected in the works of K.A. Abulkhanova-Slavskaya, B.G. Ananiev, L.I. Antsyferova, L.S. Vygotsky, A.N. Leontiev, S.L. Rubinshtein, et al., where authors consider various aspects of the professional self-development of future teachers.

In modern psychological and pedagogical theory and practice, among scientists there is no single understanding in definition of self-development concept. Each self-development theory, proposed by the authors of one or another concept is closely related to the author's methodological standpoint, which entails a variety of approaches to its analysis.

However, no matter how different are the views of the authors on this problem, no matter how diverse are their works, most of them agree that the problem of self-development, being today particularly important, in one way or another is associated with selfactualization and self-fulfillment of the individual. Also, scientists recognize its multidisciplinary nature, some general characteristics of the problem, as well as its complexity, recognize the need to 
consider the features of combinations of internal incentives and external conditions of self-development.

Self-development can be considered as a fundamental human ability to become and be the true subject of own life. From this viewpoint self-development can be defined as the process of conscious, qualitative, and irreversible change of moral qualities, intellectual and social capabilities of the personality, own physical, mental, and spiritual forces aimed at achieving the ideal image of a holistic personality.

The conducted theoretical analysis of the literature has shown that the "self-development" is integrated concept. Its study has a centuries-old history, and is based on the writings of philosophers, educators, and psychologists. Today in pedagogics and psychology we can note the following directions in consideration of the category of personality self-development:

1) self-development as a fundamental ability, the highest and essential human need (V.I. Slobodchikov, E.I. Isaev, F.T. Mikhailov, G.I. Zhelezovskaya, A.V. Eliseeva, O.S. Anisimov, V. A. Petrovsky, I.S. Yakimanskaya, B.G. Ananiev, L.I. Antsiferova, L.I. Bozhovich, M.I. Lisina, V.N. Myasishchev, D.N. Uznadze, I.F. Kharlamov, B.Z. Vulfov, V.D. Ivanov, et al.);

2) self-development as self-building (L.S. Vygotsky, A.G. Asmolov, O.S. Gazman, V.V. Davydov, A.N. Leontiev, D.B. Elkonin, V.F. Morgun, N.Yu. Tkacheva, L.N. Kulikova, V.S. Mukhina, N.A. Nizovskykh, V.M. Rozin, B.A. Sosnovsky, V.V. Stolin, R.M. Granovskaya, Yu. S. Krixhanskaya, A.I. Kochetov, A.N. Lutoshkin, I.L. Ruvinsky, et al.);

3) self-development as "the development of one's self", leading to self-actualization (Sh.A. Amonashvili, M.P. Shchetinin, K.A Abulkhanova-Slavskaya, S.L. Rubinshtein, D.A. Leontiev, L.N. Kulikova, B.S. Bratus, G.A. Zuckerman, B.M. Masterov, A.B. Orlov, N.B. Krylova, N.N. Mikhailova, N.V. Pakulina, T.V Frolova, S.M. Yusfin, A.A. Bodalev, T.V. Anokhina, et al.).

In the late XXth - early XXIst century in scientific literature selfdevelopment of personality is associated with dynamic changes in society. Modernization of the education system, carried out today, leads to the restructuring of educational organizations, which need to find new forms of work with students, allowing ensuring their self-development in accordance with the basic requirement of the state educational standard of the next generation. In many ways, the potential of such work lies in the wide interaction of all participants involved in educational activities and the actualization of creative and personal resources of educators and students [1].

According to the State development program of education in the Republic of Kazakhstan, the content of higher education should be focused on "...ensuring self-determination of the individual, creating conditions for its self-actualization"; "...formation of a person and a citizen, prepared to enter into the modern society, and focused on improving this society" [2].

This program defines the need to form in the future teacher's personality the ability and willingness not only to apply their knowledge and skills in constantly changing conditions, but also be able to comprehend the meaning of their professional activities, to accept professional values, and be ready for constant professional self-development.

Thus, in the XXIst century the idea of personality selfdevelopment becomes one of the priorities in the higher professional and pedagogical education system. This need of society has increased the attention of the global pedagogical community to the need of realizing that the analysis of the study of the professional and personal self-development process in modern conditions requires its systematic and holistic study.

The concept of "self-development" has no unambiguous definition. In Humanities practice and theory, it is interpreted from the perspective of the authors.

We tried to define the essence of the "self-development" category based on different interpretations.

In the Large Explanatory Dictionary of the Russian Language by S.A. Kuznetsov, self-development is understood as the development through the use of one's own resources, without the influence of any external forces, while in the philosophical dictionary selfdevelopment has similar interpretation as the self-movement of the individual [3]

Self-development of an individual is a process of enrichment of active abilities of a person and other personal qualities in the course of various types of expedient activity of a person, which is based on the desobjectivation (assignment) of social experience and cultural achievements embodied in the realities involved in this or that activity process [4].

In psychology, V.I. Slobodchikov and E.I. Isaev were among the first to define and substantiate distinctive features of selfdevelopment, giving the following definition to this concept: selfdevelopment is the fundamental ability of a person to become and be a true subject of own life, to turn his own vital activity into a subject of practical transformation [5].

In the works of L.I. Antsyferova self-development is seen as a feature of the higher level of personality development, when a person becomes the subject of the own life path which is determined by the degree of individuality and personal freedom, i.e. the freedom to discover, experience, and resolve the contradiction by own actions, modifying the level of personality organization as a system, and to change its mode of functioning [6].

Anufrieva D.Yu., when exploring the self-development phenomenon, came to the conclusion that this phenomenon was due to the activity of internal factors (potential abilities), and would become more manageable if its mechanism was based on conscious regulation of its own potential capabilities in pedagogical activity [7]. The conducted analysis of scientific definitions allows making the conclusion that self-development plays a leading role in the professional development of the future teacher.

Currently, the ways to identify the essence of self-development, as well as the means to improve the efficiency of personal and professional self-development of students are being elaborated (I.G. Grigoriev, I.G. Egorov, L.N. Kulikova, G.V. Morozova, S.D. Polyakov, A.I. Reznik, et al.). However, despite a significant number of scientific papers dealt with this topic, the aspect concerning psychological and pedagogical support of students' selfdevelopment in the modern system of professional education of pedagogical profile still remains poorly studied.

One of the avenues in higher education modernization is directed today towards competence approach in the course of training of pedagogical profile specialists. To date, the Resolution of the Government of the Republic of Kazakhstan on approval of the State compulsory standard of higher education No. 1080 of August 23,2012 , is quite timely. It defines the requirements for the students' level of training on the basis of Dublin Descriptors of the first-level (bachelor degree course), expressed through competences. In this case, the development of competence implies the training of specialists, who are not only capable and ready to apply their knowledge, skills, and abilities in the course of professional activity in an ever-changing environment but also realize the meaning of their professional activities as well as are ready to accept professional values and be prepared for continuous professional self-improvement [8].

The studies of professional competence conducted by A.K. Markova, S.A. Druzhilov, E.F. Zeer, O.N. Shakhmatova, V.V. Abashina, et al., identify the following structural components of competence as integrative personal qualities: cognitive, activity, operational and technological, personal, reflexive, and motivational. In the framework of our article we have considered the valuesemantic component in the context of professional and personal self-development. As a source of activity and one of the main determinants of human behavior, the value-semantic component provides professional growth and self-improvement of future teachers.

This means that human development is determined by another factor - value-semantic aspect. That is, for a person, development is the goal, value and meaning of his own life [5].

Value orientations are the most important component of personality structure. Value orientations of a person, connecting his inner 
world with the surrounding reality, form a complex multilevel hierarchical system occupying a boundary position between needmotivational sphere and the system of personal meanings.

The value-semantic component includes elements of the personality structure that characterize the semantic aspect of its orientation. Values are one of the most important semantic structures forming the perspective, the model of the future that has the greatest importance for the person. Znakov V.V. considers values as a conscious content, which can become a real motive of human activity, leading to self-development. The aggregate of personal and professional values determines the process of personal development, influencing its dynamics, and serves as the central mechanism that determines self-development at all stages of personal and professional development.

Personal and professional values influence possible ways and means of self-development, forming the purposes and the internal program of its implementation. As shown by the conducted research, the subject's professional and personal values determine the self-development process, defining the values most important in terms of sense-making of prospects [9]. If there are contradictions among divergent values in the structure of the valuesemantic sphere, they can encourage a person to resolve the existing discrepancies that ultimately stimulates self-development. The level of personal and professional self-development can be determined by the maturity of value-semantic sphere, which is clearly shown in the study conducted by S.A. Minyurova [10].

In consequence of the analysis of the problem concerned overcoming critical situations, F.E. Vasilyuk in his monograph "Psychology of experience" touches upon the issue of value sensemaking in the context of emotional experience. Vasilyuk cites the utterance of Halperin P.Ya. that "the value internally illuminates person's entire life filling it with simplicity and true freedom". As he notes in that respect, the values acquire the qualities of real motives and sources of meaningfulness of being, leading to the growth and improvement of the personality in the course of its own consistent development. Value orientations, thus being a psychological organ, a personal growth and self-development mechanism, are themselves developing in their nature and represent a dynamic system [11].

The theoretical analysis of studies devoted to the issues of professional training of students and their readiness for pedagogical activity allows drawing a conclusion that this is complicated education which has to be formed under the influence of special training and own practical experience. We consider it necessary to note that the readiness for pedagogical activity can be formed only in the course of professional training. Training represents a process, while the preparedness of students for selfdevelopment is, on the one hand, the goal, while, on the other hand - the result of this process.

Thus, the formation and improvement of the orientation level of value-semantic competences as one of the conditions for stimulation the professional and personal self- development of future students is a complex professional and personal education, consisting of a number of elements, which include professionally significant qualities.

\section{Methods}

Our research aims at building a model to stimulate professional and personal self-development of future teachers. In the consequence of the analysis of the set research tasks, we proposed the prognostic model containing the qualification characteristic, requirements to the future specialist, and personal qualities needed for mastering the profession. The proposed model is used to simulate self-development of professional and personal qualities.

Structuring this model was accompanied by a phased implementation of the actions aimed at achieving the research objective.

The first development stage of the model involved studying normative documents, determining the factors that significantly af- fected the professional and personal self-development in the framework of the problem under consideration. The initial stage included the transition from the real phenomenon to the construction of an adequate model.

The second stage assumed measurement and the mathematical analysis of theoretical results of the obtained model for its further development.

The third stage included definition of the adequacy of implementing of the proposed model into practice.

In consequence of the analysis of theoretical and methodological approaches such as activity-personal, value-semantic, subjective, competence-based, system-based, and acmeological ones, we determined the structure of the functional model stimulating professional and personal self-development of future teacher, which is presented in Figure 1.

\begin{tabular}{|c|c|c|c|}
\hline \multicolumn{4}{|c|}{$\begin{array}{l}\text { State social order: } \\
\text { need of society for specialists with a high level of professional and personal } \\
\text { self-development }\end{array}$} \\
\hline \multirow[t]{2}{*}{$\begin{array}{l}\text { Target } \\
\text { module }\end{array}$} & $\begin{array}{l}\text { Diagnostic } \\
\text { module }\end{array}$ & $\begin{array}{l}\text { Organizational- } \\
\text { activity module }\end{array}$ & $\begin{array}{c}\text { Evaluation-reflexive } \\
\text { module }\end{array}$ \\
\hline & \multicolumn{2}{|c|}{ Functions } & \\
\hline Conceptual & Diagnostic & Developing & Estimation-criterial \\
\hline Components & Criteria & Indicator & Principles \\
\hline \multicolumn{2}{|c|}{$\begin{array}{l}\text { Building of an individual trajectory } \\
\text { to inspire professional and personal } \\
\text { self-development }\end{array}$} & \multicolumn{2}{|c|}{$\begin{array}{l}\text { Organizing the pedagogical process of future } \\
\text { teachers' self-development through the } \\
\text { development of professional and personal } \\
\text { competencies }\end{array}$} \\
\hline
\end{tabular}

Fig. 1: Structural and functional model stimulating professional and personal self-development of future teachers

Thus, we assume that the development of value-semantic competences serves the basis for stimulating professional and personal self-development of future teachers. In the structural model we distinguish the motivational, cognitive, and value-semantic components. As part of our study, we examined in detail and empirically investigated the value-semantic component of the proposed structural and functional model stimulating professional and personal self-development of future teachers.

The proposed model stimulating professional and personal selfdevelopment is a basis for carrying out the ascertaining, forming, and control experiment.

\section{Results}

Empirical research of self-development stimulation based on formation and increase of the orientation level of value-semantic competences in future teachers as a condition of professional and personal qualities' development was carried out on the basis of Shakarim State University of Semey (Kazakhstan) in the 20172018 school years.

In the empirical study, the sample size was 193 students of the faculty of history and pedagogy. The respondents were $1^{\text {st }}$ to $4^{\text {th }}$ year students of specialties "Pedagogics and psychology", "Music education", "Vocational education", "Pedagogics and methods of primary education", and "Fine arts". Purpose-in-Life Orientation test by D.A. Leontiev, and A. Shostrom's Personal Orientation Inventory (POI) were used as diagnostic methods to study the value-semantic orientation of the students.

Purpose-in-Life Orientation test by D.A. Leontiev contains five scales: purpose in life, the life process or interest and the emotional saturation of life, the effectiveness of life or satisfaction with self-implementation, the locus of control - I, and the locus of control - life or controllability of life. 
1. Purpose in life. This scale characterizes the presence or absence in the life of testee the purpose in the future, which gives life meaning, direction, and time perspective. Low scores even at the overall high level of expectations will be inherent in the person living in the present or past. At the same time, high scores can characterize not only the purposeful person, but also the daydreamer, whose plans do not have real support in the present and are not supported by personal responsibility for their implementation. These two cases are easy to distinguish, given the indicators measured on other scales.

2. The life process or interest and the emotional saturation of life. The content of this scale coincides with the well-known theory that the only meaning of life is to live. This scale shows whether the testee perceives own life process as interesting, emotionally rich, and full of meaning. High scores on this scale and low scores on the other scales are peculiar to the hedonist living in present. Low scores are a sign of dissatisfaction with own live in the present; at the same time, however, memories of the past or focus on the future may give full meaning to the present.

3. The effectiveness of life or satisfaction with self-implementation. This scale reflects an assessment of the past segment of life, a sense of just how productive and meaningful was this part of life. High scores on this scale and low scores on the rest scales characterize the person who lives his life, who has everything in the past, though the past can give meaning to the rest of life. Low scores mean dissatisfaction with the lived part of life.

4. The locus of control - I (I am the master of my life). High scores correspond to the notion of oneself as a strong personality with sufficient freedom of choice to build own life in accordance with set goals and ideas about its meaning. Low scores mean disbelief in own capability to control the events of own live.

5. The locus of control - life or controllability of life. High scores assure that a person is able to control his life, freely make decisions and implement them. Low scores are indicative to fatalism, the belief that human life is not subject to conscious control and that freedom of choice is illusory, and making any plans for future is meaningless.

The study involved 193 respondents. Among them, 164 were female respondents, and 45 - male respondents. The study of the level of meaningfulness of life using Purpose-in-Life Orientation test by D.A. Leontiev has shown that the average score of student sample equals to 103 , which is the average for males, and above the average - for females.

In consequence of the diagnostic study, average indicators of the purpose-in-life orientation level were revealed according to the following scales: the scale of the purpose in life -21 ; the life process or interest and the emotional saturation of life -22 ; the effectiveness of life or satisfaction with self-implementation - 18; the personal locus of control - 24; the locus of control - life or controllability of life - 21 (Fig. 2).

The analysis of the obtained results has shown that in general the level of purpose-in-life orientations of the respondents is at the average level. These results indicate that, in general, the testees perceive their lives as meaningful and emotionally rich, and are satisfied with the process and result. Most students are able to control their lives in accordance with their goals and ideas about its meaning. The average indicator on satisfaction with selfimplementation indicates that respondents are currently looking for ways to achieve their goals leading to self-improvement and self-development. This indicator is a driving force in the desire of the future teacher personality to master the pedagogical skills.

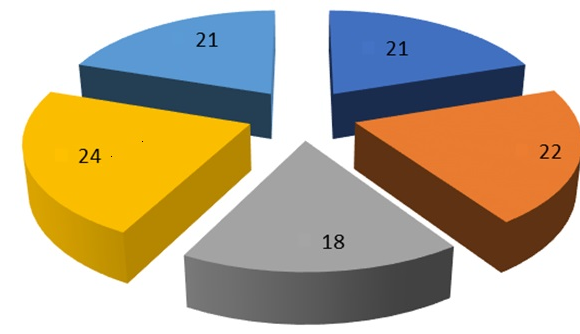

- Purpose in life

life process or interest and the emotional saturation of life effectiveness of life or satisfaction with selfimplementation

- locus of control-1

- locus of control - life or controllability of life

Fig. 2: Indicators of the level of formation of purpose-in-life orientations

Shostrom's POI is designed to survey mentally healthy (with no severe psychopathology) adults (older than 15-17 years of age). The specificity of the phenomenon under study (self-actualization) and the nature of the test itself, the complexity of its judgments that require serious reflection, allow recommending this test for examining mainly persons with higher education.

The main trends in the development of modern pedagogy both in our country and abroad are aimed at humanizing the education sphere, the comprehensive development of the creative potential of students, the formation of equal, partnership relations, the spirit of cooperation between teachers and students. These trends are more or less characteristic of the different fields and levels of education (primary, secondary, and higher education). Therefore, to describe the personality reference model of both a teacher (teacher, educator), and a student (pupil, student), pedagogical psychology increasingly appeals to the theories that are developing in the mainstream of existential-humanistic direction in psychology (K. Rogers, F. Pearl, V. Frankl, et al.).

One of the most widely known theories in the framework of this approach is A. Maslow's concept of self-actualizing personality. The popularity of this theory is associated, on the one hand, with the heuristic concept of self-actualization and the possibility of its operationalisation and use in empirical research. On the other hand, this personality model, emphasizing the positive manifestations of human nature, such as creativity, altruism, love, friendship, etc., serves as a benchmark in the process of education, the formation of the student's personality, and building a system of relations between the teacher and the student.

The concept of self-actualization is synthetic, since it includes comprehensive and continuous development of creative and spiritual potential of a person, the maximum implementation of all his capabilities, adequate perception of others, the world and his place in the world, the richness of the emotional sphere and spiritual life a high level of mental health and morality. In one of his works, Maslow defines self-actualization as "... the desire for selffulfillment, namely, to the tendency for him to become actualized in what he is potentially. This tendency might be phrased as the desire to become more and more what one is, to become everything that one is capable of becoming."

In many ways, Shostrom connects manifestations of selfactualization with the concepts of "competence in time" and "reliance on themselves." In his opinion, self-actualizing personality is the most competent in time. This personality deals with life entirely in the present, although uses the past and the future to make the present more meaningful.

Self-actualizing personality tends to be more independent in his orientation towards both internal leadership and leadership on the part of others. However, compared with non-self-actualizing personality, this personality possesses greater reliance on himself, and greater independence from others.

POI was developed on the basis of Maslow's theory of selfactualization, the concepts of psychological perception of time and temporal orientation of the subject of F. Perl and J. May, the ideas of K. Rogers, and other theorists of existential-humanistic direction in psychology. Specific POI questions were selected from a large set of critical, first of all, behavioral and value indicators that distinguished a healthy self-actualizing person from neurotic person. To identify these indicators Shostrom took interview from a number of practicing psychologists working in line with the exis- 
tential-humanistic approach to psychotherapy and summarized their experience. Work on the analysis and selection of judgments included in the test was carried out within five years.

The POI consists of 150 questions, compiled on the principle of forced choice, and allows registering two basic and ten additional parameters of self-actualization. The scales themselves, or, in other words, the components of self-actualization were selected similarly to the test questions on the basis of a survey of psychotherapists and characterize the main spheres of life of a selfactualizing person.

The analysis of the results obtained was carried out on 11 test scales.

1. The time orientation scale shows to what extent a person lives in the present, without postponing his life "for later" and not trying to find shelter in the past. The high result is typical for those people, who are well aware of the basic value of life which is formulated as "to live here and now", who are able to enjoy the current moment, not comparing it with past joys and not devaluing it by anticipating future successes. Low results are typical for suspicious and underconfident persons, who are immersed in the experiences of the past with high aspiration to achievements.

2. Scale of values. A high score on this scale indicates that a person shares the values of a self-actualizing person, such as truth, goodness, beauty, integrity, absence of duality, vitality, uniqueness, perfection, accomplishment, justice, order, simplicity, doing easy without effort, play, and self-sufficiency.

3. A view of human nature can be positive (high score) or negative (low score). This scale describes the belief in people, in the power of human capabilities. The high index can be interpreted as a stable basis for sincere and harmonious interpersonal relations, natural sympathy and trust in people, honesty, impartiality, and goodwill.

4. The high need for cognition is characteristic of a selfactualizing person, always open to new experiences. This scale describes the capacity for being-knowledge, i.e. pure thirst for the new, interest towards the objects that are not directly related to meeting any specific needs. Such cognition is more precise and effective, since its process is not distorted by desires and aspirations, and a person is not inclined to judge, evaluate, and compare. He simply sees what is and appreciates it.

5. Striving for creativity or possession of creative potential as an indispensable attribute of self-actualization, which can simply be called a creative attitude to life.

6. Independence. The self-actualizing person is independent and free. However this does not mean alienation and loneliness. Independence presupposes trust in oneself, in own opinion and outlook on life, and self-sufficiency.

7. Spontaneity is a quality that stems from self-confidence and trust in the world around that is peculiar to self-actualized people. The high score on spontaneity scale indicates that selfactualization has become a way of life rather than a dream or aspiration. Spontaneity correlates with values such as freedom, naturalness, play, and doing easy without effort.

8. Self-understanding. The high score on this scale indicates about human sensitivity to own desires and needs. Such people are not inclined to substitute their own tastes and assessments by external social standards. The indicators on scales of self-understanding, spontaneity, and autosympathy, as a rule, are linked with each other. Low score on the scale of self-understanding is characteristic of underconfident people who are guided by the opinion of others.

9. Autosympathy means positive attitude of a person towards himself. Autosympathy does not mean stupid complacency or uncritical self-perception.

10. The scale of in-touch capabilities is used to measure sociability of the personality, his ability to establish strong and friendly relations with others. In the self-actualization diagnostic questionnaire (SAMOAL), in-touch capabilities are understood not as a level of communicative abilities of the individual or effective communication skills, but as a general predisposition to mutually beneficial and pleasant contacts with other people.

11. The scale of flexibility in communication correlates with the presence or absence of social stereotypes, the ability to adequately express oneself in communication. High scores testify to harmonious interaction with surrounding people, ability to self-disclosure. People with a high score are focused on personal communication, and they do not tend to resort to deception or manipulations. Low scores are typical for people who are not confident in their attractiveness, in the fact that they are interesting to the interlocutor, and that communication with them can bring pleasure.

As a consequence of the diagnostic study, indicators of the selfactualization level were identified on the following scales: scale of orientation in time -56.3 ; scale of values -68.7 ; scale of view of nature -53.2 ; scale of high need for cognition -58.3 ; scale of pursuit of creativity -56.3 ; scale of independence -56.0 ; scale of spontaneity -63.9 ; scale of self-understanding -58.3 ; scale of autosympathy -69.3 ; scale of in-touch capabilities -56.3 ; and scale of flexibility in communication - 59.8 (Fig. 3).

The analysis of the results obtained has shown that in general, the self-actualization in respondents is at the average level. This is a positive indicator and a stimulating factor leading to selfdevelopment and mastering the ways of individual improvement.

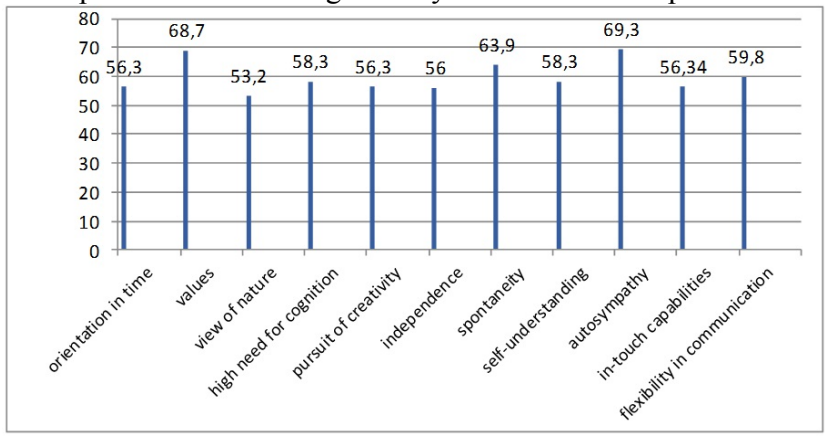

Fig. 3: Indicators of self-actualization and self-development

The conducted correlation analysis has shown that there are direct statistically significant interrelations among the level of selfdevelopment, self-actualization $(\mathrm{g}=0.438)$ and purpose-in-life orientations $(g=0.403)$, value orientations $(g=0.328)$, and the level of self-development $(g=0.386)$. These relationships can be combined into a single value-semantic block, in which the level of self-development is determined by readiness for it and is realized based on the existing values of personal and professional selfdevelopment.

\section{Discussion}

Thus, the results of empirical research have shown the following: - students who consider personal self-development as an important value of life, who are ready for self-knowledge and confident in their own effectiveness are inclined to active professional and personal self-development;

- students to whom self-development value is predominant, are characterized by high level of self-development, motivational readiness for self-development and self-knowledge.

Thus, the obtained results of empirical research evidence that the purposeful orientation of value-semantic competences is a stimulating factor leading to professional and personal self- development.

\section{Conclusion}

The study of the theoretical foundations of stimulation based on the formation and improvement of the orientation level of valuesemantic competences of future teachers as one of the conditions for the development of their professional and personal qualities, as 
well as the results of conducted experimental work have allowed to draw the following conclusions:

1. A theoretical analysis of interpretations on the stimulation of professional and personal self-development, and the use of the explicative potential of theories such as value-semantic, acmeological, activity-personal, subjective, competence, and systemic approaches, allowed expanding the concept of value-semantic competences as a system-wide construct. This construct is a necessary condition for human self-development as an open system, a new psychological formation, providing the process of professional and personal development of the personality, its growing abilities to make independent and responsible choices, its ability to exercise activity when realizing own capabilities and potential. 2. Considering the process of raising the level of professional and personal competences as one of the factors leading to the stimulation of self-development, we define it as a complex professional and personal education.

3. The positive attitude of students to active professional and personal self-development, perception of it as an important vital value, readiness for self-knowledge and confidence in their own efficiency serve as indicators of the value-semantic component of the desired stimulation of self-development in students. Students, who consider the value of self-development as a predominant category, are characterized by high level of self-development, motivational readiness for self-development and self-knowledge.

4. An empirical study of the $1^{\text {st }}$ to $4^{\text {th }}$ year students have been carried out aiming at identification of the level of their readiness for self-development based on the formedness of value-semantic orientation as one of the factors in the development of professional and personal qualities.

5. The possibilities of pedagogical process at higher education institution on formation of students' readiness to self-development on the basis of value-semantic orientation as one of factors of development of professional and personal competence have been revealed.

\section{References}

[1] Ivanova IV, Kosogorova LA \& Shulman MG (2014), Obrazovanie kak obespechivayushchij resurs ehkonomiki i strategicheskij orientir $\mathrm{v}$ ee innovacionnom razvitii [Education as an economy resource and a strategic reference point in its innovative development]. Proceedings of the second extramural science-to-practice conference with international participation "National innovation system: The best regional practices".

[2] Gosudarstvennaya programma razvitiva obrazovaniya i nauki $v$ RK na 2016-2019 [The state program of education and science development in the Republic of Kazakhstan for 2016-2019]. Astana, 2016.

[3] Kuznetsov SA (2010), Bol'shoj tolkovyj slovar' russkogo yazyka [The Large Explanatory Dictionary of the Russian Language]. Institute of Linguistics of the Russian Academy of Sciences. St. Petersburg: Norint.

[4] Rapatsevich ES (2005), Pedagogika: Bol'shaya sovremennaya ehnciklopediya [Pedagogics: A Large Modern Encyclopedia]. Minsk: Modern Word.

[5] Slabodchikov VI \& Isaev EI (2000), Psihologiva razvitiya chelove$k a$ [Psychology of human development]. Moscow.

[6] Antsyferova LI (2000), Psihologicheskoe soderzhanie fenomena sub"ekt i granicy sub"ektno-deyatel'nostnogo podhoda [Psychological content of the subject phenomenon and the boundaries of the subject-activity approach]. In: A.V. Brushlinsky, M.I. Volovikova, V.N. Druzhinin (Eds.). The problem of the subject in psychological science. Moscow.

[7] Anufrieva DYu (1996), Samorazvitie uchitelya v processe podgotovki $k$ pedagogicheskoj deyatel'nosti [Self-development of teacher in preparation for teaching activities]. Ph.D. thesis in pedagogy. Moscow.

[8] Abibulaeva AB \& Zhilgildinova MZh (2017), Teoreticheskie osnovy formirovaniya motivacii $\mathrm{v}$ kontekste professional'no- lichnostnogo samorazvitiya [Theoretical framework of forming motivation in the context of professional and personal self-development]. Proceedings of the 3rd International science-to-practice conference
"Contemporary issues of psychology and pedagogics in the modern world”. The Peoples' Friendship University of Russia.

[9] Gagarina ZhG (2013), Psihologicheskaya kompetentnost' v strukture lichnostno - professional'nogo samorazvitiya specialistov socionamicheskoj sfery [Psychological competence in the structure of personal and professional self-development of specialists in socionomics sphere]. Saransk: Mordovia State University.

[10] Minyurova SA (2009), Psihologicheskie osnovaniva vybora strategii samorazvitiya $v$ professii [Psychological grounds for choosing self-development strategy in the profession]. Ph.D. thesis in psychology. Moscow.

[11] Vasilyuk FE (1984), Psihologiya perezhivaniya [Psychology of experience]. Moscow: Moscow State University. 